\title{
COMMENTARY
}

\section{Habituating Antelope and Bison to Cooperate With Veterinary Procedures}

\author{
Temple Grandin \\ Department of Animal Science \\ Colorado State University
}

Undomesticated, wild, nonhuman animals with an excitable temperament frequently sustain injuries when handled for veterinary procedures such as blood sampling or injections. Both bison and antelope may become agitated when they are restrained, often resulting in broken horns. Also, antelope may panic when restraint is forced on them suddenly. This research group has successfully trained both Bongo and Nyala antelope to enter a box voluntarily for food rewards. While quiet, nonsedated antelope were standing in the box, blood samples were taken from their rear legs. Three Bongo antelope who had been conditioned to stand in the box had low cortisol levels that averaged $4.4 \pm 3.4 \mathrm{ng} / \mathrm{ml} \mathrm{in} \mathrm{a} \mathrm{male} \mathrm{and} 8.5 \pm 4.7 \mathrm{ng} / \mathrm{ml}$ in two females. The unsedated animals were held in the box for 10-20 min to allow cortisol levels to rise. These values were much lower than cortisol levels reported in the literature for restrained unsedated wild ruminants and domestic cattle who are not habituated to restraint. Because antelope are flighty animals, each new step in the conditioning process had to be introduced in very small steps to prevent panic. In another experiment, bison calves were trained to walk through the handling chutes for feed rewards. In both species, avoiding panic is important, especially in the early stages of training.

There is a need for methods to prevent the serious injuries that often occur when wild, undomesticated, ruminant, grazing nonhuman animals are handled for veterinary procedures. I have observed that antelope and bison often are injured and break horns during routine handling. Even when these animals are handled care-

Requests for reprints should be sent to Temple Grandin, Department of Animal Science, Colorado State University, Fort Collins, CO 80523. 
fully, they are likely to ram into fences and struggle violently when restrained. Bison confined in a small pen in a handling facility sometimes gore each other.

My colleagues and I have developed practical methods for habituating and conditioning antelope and bison to being handled. Animals with a flighty, excitable temperament are more likely than those of calmer temperament to become fearful when a novel experience is suddenly forced on them (Grandin, 1997; Grandin \& Deesing, 1998). The difference between a domestic ruminant such as cattle and a wild ruminant such as antelope or bison is the intensity of their reaction when they are handled. Price (1998) stated that part of the process of domestication is culling of the most excitable, difficult-to-handle individuals. This process of domestication of deer already has started in New Zealand. Mathews (2000) observed that deer have become calmer and calmer since the beginning of deer farming 30 years ago.

Animals with an excitable temperament will not habituate to a forced, nonpainful handling procedure. Even in domestic cattle, new experiences and novelty are stressful (Dantzer \& Mormede, 1983; Moberg \& Wood, 1982; Stephens \& Toner, 1975). E. K. T. Lanier et al. (1995) found that some pigs habituated to being placed repeatedly in a swimming pool, and others remained fearful with elevated adrenaline levels. Both scientific studies and practical experience have shown that animals with a flighty, excitable temperament do not habituate readily to forced handling and restraint.

After seeing numerous broken horns and several serious injuries, I concluded that the only way to prevent stress and injury to bison and antelope was to condition them to cooperate voluntarily during handling, restraint, and veterinary procedures.

Many different species have been conditioned successfully to cooperate with veterinary procedures. Primates, dolphins, elephants, pigs, and sheep will either extend a limb for injections or enter a restraining device voluntarily (Calle \& Bornmann, 1988; Grandin, 1989; Panepinto, 1983; Wienker, 1986). One of the problems with bison and antelope, compared with the species just listed, is that they are more excitable and flighty. We had to develop conditioning methods that would not trigger a massive destructive panic reaction.

\section{CONDITIONING METHODS}

Successful methods for conditioning Nyala and Bongo antelope to enter a wood crate voluntarily for blood sampling already have been reported (Grandin et al., 1995; Phillips, Grandin, Graffam, Irlbeck, \& Cambre, 1998). Table 1 outlines the conditioning procedures. During our work, we observed some important basic principles. To prevent a massive fear response early in the conditioning process, the antelope had to be conditioned slowly and carefully to all the sounds associated with the crate (see Figure 1). 
TABLE 1

The Advantages of Training Antelope to Cooperate With Veterinary Procedures

\begin{tabular}{lcc}
\hline & \multicolumn{2}{c}{ Time Required (Days) } \\
\cline { 2 - 3 } & Nyala & Bongo \\
\hline $\begin{array}{l}\text { Acclimate and habituate the animals to the presence of a shipping or } \\
\text { transfer crate in the stall. At this stage of training, the animals can } \\
\text { walk by the crate to go outside to the exhibit. }\end{array}$ & 7 & 7 \\
$\begin{array}{l}\text { Habituate to handling crate and movement of the vertical slide } \\
\text { doors. Barn door closed against the crate. Animals must walk } \\
\text { through the crate to go to outdoor exhibit. }\end{array}$ & 10 & 17 \\
$\begin{array}{l}\text { Train to enter crate and eat treats with rear door open and front door } \\
\text { closed. }\end{array}$ & 21 & 21 \\
$\begin{array}{l}\text { Initial capture in crate and release immediately. } \\
\text { Habituate to stand captured in the crate for up to 10 min while } \\
\quad \text { continually being fed treats. }\end{array}$ & 7 & 7 \\
$\begin{array}{l}\text { Habituate to open bleed hole door and being touched on the rear leg. } \\
\text { Condition to simulated blood sampling (increasingly hard pinches). } \\
\quad \text { Halfway through this period, treats were withheld and food was } \\
\text { given only as a reward after the animal had stood still. }\end{array}$ & 14 & 14 \\
$\begin{array}{l}\text { Successful blood sampling of all animals. } \\
\text { Total training days }\end{array}$ & & 14 \\
\hline
\end{tabular}

On the 1st day, the vertical slide door on the box was moved about $2 \mathrm{~cm}$. This caused the antelope to turn their heads toward the sound. The instant the antelope oriented toward the sound, the door movement was stopped. (It took 10-17 days to habituate the antelope to the door movement.) Each day the door was moved more. Care was taken not to push the animals past the orienting behavior, because when these animals panic they react explosively and ram into walls.

As the animal's excitability increases, new experiences, sights, and sounds must be introduced in smaller and smaller steps to avoid panic. The first phase of conditioning an excitable animal is habituation to the procedures to avoid panic. The second phase of the conditioning procedure uses standard operant conditioning methods. With all species, great care must be taken to ensure that an animal's first experience with something new is either positive or neutral. Both practical experience and research show that if an animal's first experience with something new is frightening or painful, the animal will actively avoid the place where the aversive event occurred. Miller (1960) found that if a rat was shocked the first time it entered a new arm in a maze, it would never enter that area again. First experiences with new places make a big impression on animals. 


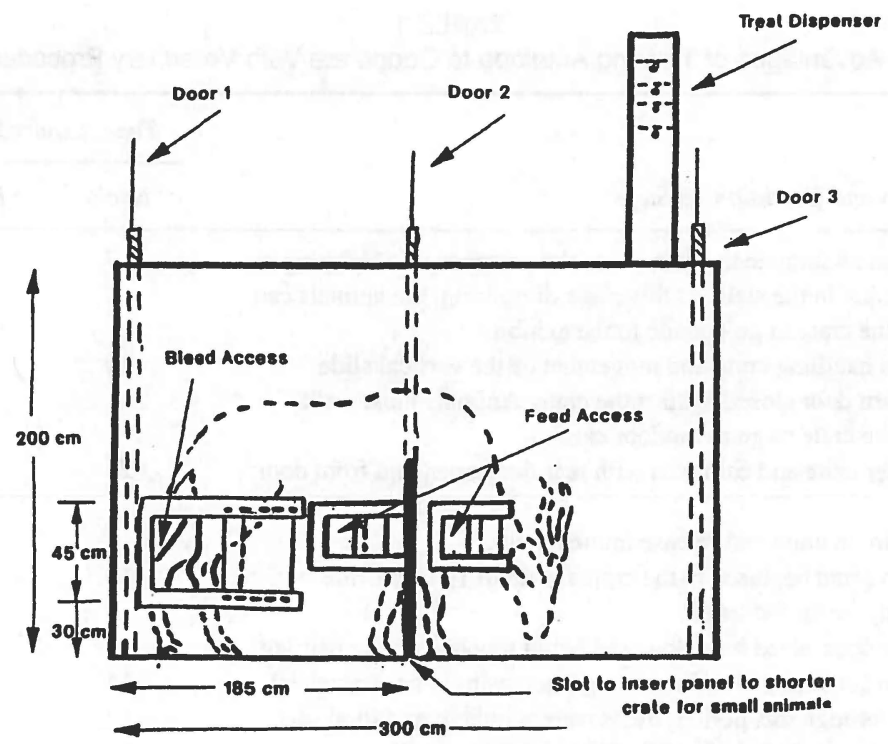

FIGURE 1 Handling crate for Bongo antelope. The $20 \times 20$-cm square dispenser was made of plywood and stood $120 \mathrm{~cm}$ high. It had four flip-down shelves that operated like those of a candy vending machine. Pulling cables that were attached to pins supporting each shelf dispensed spinach. Foam tape on the leading edge of each shelf reduced noise when a shelf was released. The crate was created to hold a Bongo antelope who has been conditioned for blood sampling from the rear leg.

\section{Choosing Food Treats}

The food used to reward the animals must be a highly palatable treat that is not part of their regular diet. We tried many foods to find the animal's favorite treats. For Nyala, we used yams and carrots. Bongo liked spinach, and bison liked pretzels, peanut butter, and a molasses-based cattle supplement. Early in the conditioning procedure, the treat was used as a "bribe" to induce the antelope to enter the crate. Later in the process, the treat was withheld until the animal performed the desired behavior such as standing still. Timing is critical for the animal to associate the treat with the desired behavior.

\section{Conditioning to Blood Sampling From the Rear Leg}

The antelope first were conditioned to having their rear legs and other parts of their hindquarters touched. At first, they were given treats continually to keep them distracted from being touched. After a few successful blood samplings, they learned that they could kick the needle away. At this point, the treats were 
withheld until the animals stood still even for an instant. The treat was then given the instant they did the desired behavior. Figure 2 shows blood sampling from the rear leg.

People working with the animals must differentiate between panic- and fear-based kicking and learned avoidance kicking away of the needle. Fear-based behaviors are most likely to occur early in the conditioning process. Learned avoidance occurs when the animal is relaxed enough not to have a panic response.

\section{Training Bison}

My student Jennifer Lanier trained bison calves to move voluntarily through a handling facility that consisted of holding pens, a single file chute, and a squeeze chute. It was similar to a cattle-handling facility. She had 18 days to train bison before shipment to the National Western Livestock Show in Denver.

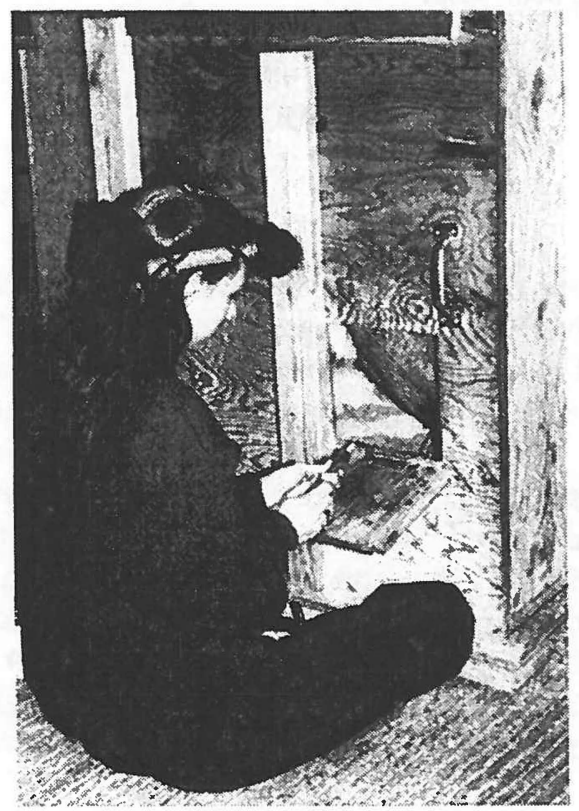

FIGURE2 Blood sampling from the rear leg of a cooperative, nonsedated Nyala antelope. Each new step in the habituation process had to be introduced in small increments to avoid a massive panic reaction. The use of a needle with a plastic tube attached makes it easier to collect the blood into a syringe. 
Bison are more flighty and fearful than cattle but less flighty than antelope. The entire training period for bison was shorter than the training period for antelope (J. Lanier, Grandin, Chaffin, \& Chaffin, 1999). The first step was to introduce the animals to operant conditioning procedures. They learned that a whistle signaled a treat reward. The reason for using the whistle was to improve safety for the handler. Unlike the antelope, who were inside a box, the bison were loose in a pen. It is safer for the handler if the animals associate treats with the whistle. This helps prevent the bison from mobbing the handler. The bison then were taught that standing still would be rewarded with treats-after they had walked through the handling facility. Over the period of 18 days, bison were walked through the facility and trained to stand in the squeeze chute. During the 18-day period, new sights and sounds gradually were introduced. The animals were habituated to the sounds of the squeeze chute clanking and banging. They were then walked through the chute and then given treats. Approximately halfway through the 18-day training period, they were stopped briefly in the squeeze chute by shutting the gates. Unfortunately, there was not enough time to train them voluntarily to accept having their necks clamped in the head gate.

\section{RESULTS}

\section{Antelope}

Blood sampling from the rear leg and injections could be done easily in unsedated, cooperative Nyala and Bongo. Three Bongo antelope who had been conditioned to stand in the box had low cortisol levels that averaged $4.4 \pm 3.4$ $\mathrm{ng} / \mathrm{ml}$ in a male and $8.5 \pm 4.7 \mathrm{ng} / \mathrm{ml}$ in two females. The unsedated animals were held in the box for 10-20 min to allow cortisol levels to rise. Glucose and creatine phosphokinase levels also were obtained and compared to levels in the animals' zoo hospital records. The mean glucose value for crate-conditioned animals was $61.25 \pm 19.45 \mathrm{mg} / \mathrm{dl}$ versus $166.5 \pm 54.59 \mathrm{mg} / \mathrm{dl}$ in individuals immobilized with a dart or pole injection. The mean creatine phosphokinase values were $70.75 \pm 17.9 \mathrm{IU}$ in crate-conditioned and 288.75 $\pm 194 \mathrm{IU}$ in immobilized animals (Phillips et al., 1998). Other veterinary procedures that have been conducted include injections in the muscle and tuberculin testing.

\section{Bison}

Approximately half of 13 bison calves received training, and the other half served as controls. There was no difference in weight gain between trained and untrained animals. After training, all bison calves were brought to the National Western Stock Show in Denver. Observers who did not know the animals ob- 
served both trained and untrained calves. When the animals were handled at Denver, the trained calves were definitely calmer. Untrained calves attempted to jump over fences and were harder to drive into the squeeze chute. However, there were no observable differences between trained and untrained bison when their necks were clamped in the head gate.

\section{DISCUSSION}

Conditioning and habituating flighty animals to handling procedures will reduce stress. The conditioned Bongo antelope had lower cortisol values when compared with untrained domestic cattle restrained in a squeeze chute. Typical cortisol values for untrained domestic cattle for squeeze chute restraint range from 20 to $63 \mathrm{ng} / \mathrm{ml}$ (Crookshank, Elisalde, White, Clanton, \& Smalley, 1979; Grandin, 1997; Lay et al., 1992; Mitchell, Hattingh, \& Ganhao, 1988; Zavy, Juniewiez, Phillips, \& von Tungelin, 1992). Morton, Anderson, Foggin, Kock, and Tiran (1995) obtained plasma cortisol levels for both physical restraint and chemical immobilization in six antelope species in Zimbabwe. They ranged from a high of $120.4 \mathrm{ng} / \mathrm{ml}$ in unsedated physically restrained waterbuck to $20.04 \mathrm{ng} / \mathrm{ml}$ in sedated Eland.

Both bison and antelope can make very specific sound and sight discriminations. Novel stimuli can trigger a massive panic response. Nyala antelope who had become fully habituated to zoo visitors along the fence of their exhibit panicked and crashed into the fence when they saw people on the roof of their barn. They had learned that people along the fence were not a threat, but people on the roof were frightening.

After the antelope in this study were fully conditioned, a handling session once a month was sufficient to maintain conditioning. We also observed that new people were able to handle the animals, but the veterinarian who previously had shot them with the dart was not able to handle them. They became agitated if they heard either his voice or footsteps.

Bison were able to differentiate between the sound of opening and closing gates on the squeeze chute from the sound of a person shaking the chute like a struggling animal. Bison who had become fully habituated to the noisy ratchet latches on the gates became visibly agitated when a person shook the chute like a struggling animal. It took several days to habituate them to the new sound. Bongo antelope were very much aware of any strange noise. They immediately turned their heads and oriented toward the sound of a video camera. Megan Phillips, their trainer, reported that she was able to calm them when they heard her familiar voice.

With both bison and antelope, having a solid barrier between the animal and the person was important. Although the animal still could see the person, the presence of the barrier helped keep the animal calm. Observations indicate that ruminant an- 
imals attempt to place a barrier between themselves and a perceived threat. Both cattle and bison will circle when threatened, and the dominant, strongest animals will push themselves to the middle of the mob. Domestic cattle remain calmer in chutes with solid sides (Grandin, 1980, 2000).

Because of their flighty nature, bison and antelope will remain calm only when they are subjected to the procedures for which they have been conditioned specifically. The bison were trained to walk through the chutes and stand in the squeeze chute with both the head gates tailgate closed. Due to time constraints, there was not enough time to gradually introduce them to having their necks restrained in the head gate. When they went to the Denver Stock Show, they remained calm while walking through the chute but became highly agitated when their necks were clamped in the head gate. People working with flighty animals must be aware that their learning is very specific. Although their learning generalized to a new but similar chute in Denver, they became highly agitated when suddenly subjected to a totally novel procedure.

\section{REFERENCES}

Calle, P. P., \& Bornmann, J. C. (1988). Giraffe restraint habituation and desensitization at Cheyenne Mountain Zoo. Zoo Biology, 7, 243-252.

Crookshank, H. R., Elisalde, M. H., White, R. G., Clanton, D. C., \& Smalley, H. E. (1979). Effect of transportation and handling of calves upon blood serum composition. Journal of Animal Science, $48,430-435$.

Dantzer, R., \& Mormede, P. (1983). Stress in farm animals: A need for re-evaluation. Journal of Animal Science, 57, 6-18.

Grandin, T. (1980). Observations of cattle behavior applied to the design of cattle handling facilities. Applied Animal Ethology, 6, 19-31.

Grandin, T. (1989). Voluntary acceptance of restraint by sheep. Applied Animal Behavior Science, 23, 257-261.

Grandin, T. (1997). Assessment of stress during handling and transport. Journal of Animal Science, 75, 249-257.

Grandin, T. (2000). Livestock handling and transport (2nd ed.). Wallingford Oxon, England: CAB International.

Grandin, T., \& Deesing, M. J. (1998). Behavioral genetics and animal science. In T. Grandin (Ed.), Genetics and the behavior of domestic animals (pp. 1-30). San Diego, CA: Academic.

Grandin, T., Rooney, M. B., Phillips, M., Cambre, R. C., Irlbeck, N. A., \& Graffam, W. (1995). Conditioning of Nyala (Tragelaphus angasi) to blood sampling in a crate with positive reinforcement. Zoo Biology, 14, 261-273.

Lanier, E. K. T., Friend, T. H., Bushong, D. M., Knabe, D. A., Champney, T. H., \& Lay, D. G. (1995). Swim habituation on a model for stress and distress in the pig [Abstract]. Journal of Animal Science, 73(Suppl. 1), 126.

Lanier, J., Grandin, T., Chaffin, A., \& Chaffin, T. (1999, October-December). Training American Bison (Bison bison) calves. Bison World, pp. 94-99.

Lay, D. C., Friend, T. H., Randel, R. D., Bowers, C. L., Grisson, K. K., \& Jenkins, O. C. (1992). Behavioral and physiological effects of freeze and hot iron branding on crossbred cattle. Journal of Animal Science, 70, 330. 
Mathews, L. (2000). Deer handling and transport. In T. Grandin (Ed.), Livestock handling and transport (2nd ed., pp. 331-362). Wallingford Oxon, England: CAB International.

Miller, N. E. (1960). Learning resistance to pain and fear effects of overlearning exposure and rewarded exposure in context. Journal of Experimental Psychology, 60, 137-145.

Mitchell, G., Hattingh, J., \& Ganhao, M. (1988). Stress in cattle assessed after handling, transport and slaughter. Veterinary Record, 122, 201-205.

Moberg, G.P., \& Wood, V.A. (1982). Effect of differential rearing on the behavioral and adrenocortical response of lambs to a novel environment. Applied Animal Ethology, 8, 269.

Morton, D. J., Anderson, E., Foggin, C. M., Kock, M. D., \& Tiran, E. P. (1995). Plasma cortisol as an indicator of stress due to capture and translocation in wildlife species. Veterinary Record, 136, 60-63.

Panepinto, L. M. (1983). A comfortable minimum stress method of restraint for Yucatan miniature swine. Laboratory Animal Science, 33, 95-97.

Phillips, M., Grandin, T., Graffam, W., Irlbeck, N. A., \& Cambre, R. C. (1998). Crate conditioning of Bongo (Tragelephus eurycerus) for veterinary and husbandry procedures at the Denver Zoological Gardens. Zoo Biology, 17, 25-32.

Price, E. O. (1998). Behavioral genetics and the process of animal domestication. In T. Grandin (Ed.), Genetics and the behavior of domestic animals (pp. 31-66). San Diego, CA: Academic.

Stephens, D. B., \& Toner, J. N. (1975). Husbandry influences on some physiological parameters of emotional responses in calves. Applied Animal Ethology, 1, 233-243.

Wienker, W. R. (1986). Giraffe squeeze cage procedure. Zoo Biology, 5, 371-377.

Zavy, M. T., Juniewiez, P. E., Phillips, W. A., \& von Tungelin, D. L. (1992). Effects of initial restraint, weaning and transport stress on baseline and ACTM stimulated cortisol responses in beef calves of different genotypes. American Journal of Veterinary Research, 53, 552-557. 
